\title{
“Some of My Best Friends...:" Reading Prejudice in Juvenal's Third Satire
}

\author{
Andrew Gallia*
}

The editing of a text sometimes raises important questions about an author's social milieu and the nature of his art. In the passage below, the speaker is Umbricius, the "friend" whose departure from Rome so vexes the narrator of Juvenal's third Satire. ${ }^{1}$ Among the litany of excuses offered for this leave-taking, Umbricius cites the hazards of urban life and the indifference of the city's wealthy classes to the plight of the less fortunate. These issues coalesce in the striking exemplum of a man who loses all his possessions in an apartment fire (3.203-11). The text of Willis' Teubner edition reads: ${ }^{2}$

lectus erat Codro Procula minor, urceoli sex ornamentum abaci, necnon et parvulus infra cantharus et recubans rupto de marmore Chiron, 205 iamque vetus Graecos servabat cista libellos, et divina opici rodebant carmina mures.

nil habuit Codrus_- quis enim negat? —et tamen illud perdidit infelix totum nihil. ultimus autem aerumnae est cumulus, quod nudum et frustra rogantem $\quad 210$

\footnotetext{
* Published in The Classical Journal 111.3 (2016). Thanks especially to Chris Nappa and the anonymous readers whose expert feedback on recent drafts greatly improved the present version. 1 3.1: quamvis digressu veteris confusus amici ("although unsettled by the departure of an old friend...”). On the use of the term amicus, see LaFleur (1975), (1976) 394-9; for confusus, Staley (2000) 85-6. Here and throughout, translations are my own.

${ }^{2}$ Willis (1997) 31.
} 
nemo cibo, nemo hospitio tectoque iuvabit.

The bed of Codrus was too small for Procula, six potikins formed the fixtures of his sideboard, together with, underneath, a little wine cup and a reclining Chiron hewn from marble, while an already old basket preserved Greek booklets and barbaric mice gnawed at the divine poems. Codrus had nothing, who would deny it? And yet this miserable man lost all that nothing. But the final dose of suffering is that, though naked and begging in vain, no one will offer him food or grant a welcoming shelter.

I leave it to others to judge the novel solution offered in line 205 , an emendation scrupulously attributed to Nisbet. ${ }^{3}$ It is Willis' other departure from the status quo of recent editions that is relevant for the present discussion: the spelling of the poor man's name in lines 203 and 208. In Clausen's Oxford text, for example, he is not Codrus, but Cordus, a spelling that can be traced back to Knoche's edition. ${ }^{4}$ Which version is correct, and how should we decide?

Although broadly disseminated in editions of the Satires published in the second half of the twentieth century, Cordus is only supported by one manuscript, U. The others-including P, the most reliable - read Codro ... Codrus where intelligible. ${ }^{5}$ This is what Housman printed in his

\footnotetext{
${ }^{3}$ Nisbet (1989) 292. The MSS, which many editors follow, give recubans sub eodem marmore Chiron. Cf. Housman (1931) 20: sub eodem e marmore Chiron. See also Courtney (1980) 182 and Braund (1996a) 209 ad loc.

${ }^{4}$ Clausen (1992) 56; Knoche (1950) 21. Cf. Braund (1996a) 60-1; (2004) 182; Miller (2005) 81 (based on Clausen); also Martyn (1987) 20.

${ }^{5} \mathrm{P}$ is in fact missing the name in 203 , but gives Codrus in 208. V has the obviously erroneous Cordrus in line 208, with Codro in 203. References to the MSS employ the sigla of Willis' apparatus.
} 
famous edition, as did his predecessors, who leaned more heavily on the authority of $\mathrm{P} .{ }^{6}$ Whereas Knoche's work on the manuscript tradition has demonstrated the importance of $U$, its authority remains insufficient to justify the widespread embrace of this variant reading. ${ }^{7}$

We should note the appearance of a similar (or, perhaps, identical) name in the opening lines of Satire $1(1-2)$ :

Semper ego auditor tantum? numquamne reponam vexatus totiens rauci Theseide Cordi?

Must I be a captive audience forever? Will I never get my payback, having endured the onslaught of strident Cordus' Theseid so many times?

Here the divergence of the manuscripts is more pronounced, but it is the first hand of $\mathrm{P}$, supported by the evidence of certain scholiasts, that provides Cordi against the Codri of the vulgate (including $\mathrm{U}$ ). Housman stressed the uncertainty of the situation, but was ultimately resigned to err on the side of the best manuscript in such cases. ${ }^{8}$ The programmatic nature of the first Satire may incline one to identify the poor apartment dweller, with his meager collection of Greek poetry books, with the author of the despised Theseid, but this does not settle the question of his name. ${ }^{9}$

${ }^{6}$ Housman (1931) 19-20. Cf. Jahn (1851) 26; whence Leo (1910) 101, etc.

${ }^{7}$ Knoche (1940) 143-79.

${ }^{8}$ Housman (1931) xv: "A critic therefore, when he employs this method of trusting the best MS, employs it in the same spirit of gloomy resignation with which a man lies down on a stretcher when he has broken both legs." Cf. Housman (1921) 73-7; Maas (1958) 18-19.

${ }^{9}$ On the other hand, Cordi here need not preclude a Codrus elsewhere (or vice versa): Baldwin (1972) 103; Ferguson (1987) 61; pace LaFleur (1976) 409-10; Braund (1996a) 209; Miller 
The public case for the name Cordus was made by Griffith in a note published the year after the appearance of Knoche's text. ${ }^{10}$ Griffith called attention to the fact that Cordus is a recognizably Roman cognomen, while the Greek name Codrus (Kó $\delta \rho \varsigma)$ ) is rarely found in Roman contexts. ${ }^{11}$ As the name more likely to be found in Juvenal's social milieu, Griffith argued, Cordus is more likely what the poet originally wrote.

But the victim of this apartment fire need not have been a real person at all. Only a few lines before his description of the poor man's possessions, the speaker identifies another resident of the doomed insula block as Ucalegon (199), a name borrowed from Vergil's description of burning Troy in Book 2 of the Aeneid (2.312, where it is taken from Homer, $I l .3 .148) .{ }^{12}$ Codrus also happens to be the name of a poet mentioned in the Eclogues $(5.11 ; 7.22,26)$, and it is plausible that Juvenal, having invoked the Vergilian onomasticon to mock-heroic effect in line 199 might return to this storehouse in 203 to generate irony and, perhaps, some pathos by recasting the bucolic Codrus as the victim of a typically urban calamity. ${ }^{13}$ Even so unreflective an adherent of the biographical approach to Juvenal's work as Highet saw the intertextual

(2005) 264. Note, however, the scholiast's comment on Lectus erat (Codro) in 3.203 (43 Wessner): pauper poeta cuius et supra (I 2) meminit.

${ }^{10}$ Griffith (1951) 138-9.

${ }^{11}$ See, for example, the names of A. Cremutius Cordus, the ill-fated historian made famous by Tacitus (Ann. 4.34-36, $\left.P I R^{2} \mathrm{C} 1565\right)$, and the Neronian proconsul Q. Marius Cordus ( $P I R^{2} \mathrm{M}$ 299). In contrast, Codrus appears in inscriptions only as the name of a freedman (C. Acilius C. 1. Codrus, CIL 6 37914) and a probable slave (Codrus Caesar(is), CIL 6 24572).

12 Anderson (1970) 15; Courtney (1980) 181; Staley (2000) 93; Jones (2007) 111. See also O’Sullivan (1978).

${ }^{13}$ On the relevance of Vergil's pastoral poetry for this satire, cf. Witke (1962); Jones (2007) $124-5$. 
potential of names such as these, but somehow critics and commentators have resisted the possibility in this case. ${ }^{14}$

The heart of the matter lies not in Juvenal's engagement with Vergil, however, but in another aspect of his poetics. It is evident that the rejection of the manuscript reading Codrus is not about the name's literary pedigree or lack of historical attestation, but instead has to do with its provenance. Griffith notes without explanation that "a Roman name is needed" at 3.203 and 208. ${ }^{15}$ Courtney's comment is less proleptic: "Umbricius would not feel sympathy for anyone with the Greek name Codrus." ${ }^{, 16}$ Indeed, one of the primary justifications Umbricius offers for leaving the city is a perceived influx of Greek immigrants, who have made it impossible for an honest Roman like himself to make a living (3.58-125). The argument for Knoche's reading of the text thus comes down to a spelling of the name that is more amenable to the perceived prejudices of one of the most xenophobic characters in all of Latin literature. It is assumed that we must be dealing with a Cordus in this passage, because that would be consistent with the outlook of a speaker whose views on Hellenism culminate in the sententia, "I cannot bear, oh countrymen, a Greek city" (60-1: non possum ferre, Quirites, / Graecam urbem).

The purpose of this article is to challenge that assumption, and in so doing to reflect upon the ways in which modern scholars have approached (and sometimes failed to confront

\footnotetext{
${ }^{14}$ Highet (1951) 375, 380-1. See, however, Nisbet (1989) 300; also Ruperti (1801) 3, who argue for Codri at 1.2. On Highet's biographical approach, see Anderson (1955); Highet (1974) 336-7; Winkler (1983) 1-7.

${ }^{15}$ Griffith (1951) 138.

${ }^{16}$ Courtney (1980) 182. See also LaFleur (1976) 410 n. 89; Ferguson (1987) 61. Working from the edition of de Labriolle and Villeneuve (1951), Serafini (1957) 321 justifies sympathy for a Greek Codrus by identifying him as a poor poet.
} 
adequately) the problem of ethnic prejudice in this Satire. The core issue is one that by now has become a commonplace in Juvenalian scholarship: the poet's creation of satiric personae who present speeches that are full of moralizing bombast, but which are also frequently incoherent in ways that draw the attentive listener's reproach back onto the speakers themselves. ${ }^{17}$ As others have pointed out, something is not quite right about Umbricius' denunciations of urban life. ${ }^{18}$ For all his bluster about invading Graeculi, this "friend" of the poet turns out to be more of a philhellene than he pretends, and his outrage at the moral decadence of the "Greek city" he is abandoning is exposed as a cover for other, less principled motivations. Not only does this undercutting of Umbricius' nativist posture confirm the playful nature of the author's satiric program, it may even reveal something about the complex interrelationship of Greek and Roman culture in Juvenal's day. Whether or not we choose to ascribe sympathy for someone with a Greek name to Umbricius' persona, the question remains essential to any attempt to interpret this satire as a reflection of Roman attitudes to Greeks under the Empire.

17 Kernan (1959); Anderson (1964). Braund (1996b) and Plaza (2006) 23-6 offer lucid summaries. See also Winkler (1983) 7-17. Contra, Highet (1974); McCabe (1986); Iddeng (2000), all of whom object to various degrees about the supposed anachronism of the persona as a construct of modern literary criticism: see now Rosen (2007) 248-68 on this point. Rosen (2007) 219-23 accepts the basic legitimacy of a persona approach, but finds it an inadequate explanation for the prominence of moralizing within the poetics of satire. See also Keane (2006) 9, who eschews the term persona in order to focus attention on the socially constituted nature of the satiric speaker's various postures.

${ }^{18}$ See esp. LaFleur (1976); Winkler (1983) 220-4; Freulund Jensen (1986); Braund (1989) 2932; Miller (2005) 248; Plaza (2006) 243-9; Jones (2007) 86. 


\section{“All That Nothing”}

Whatever name we settle on, the inventory of possessions in the above-quoted passage is enough to identify their owner as a Greek, or at least a serious devotee of the Greek lifestyle. We might try to account for some of these items - the image of Chiron (205) as an emblem of paideia (cf. Hom. Il. 11.832; Xen. Cyn. 1.1-17) and the Greek libellos (206)—by distinguishing the appreciation a Cordus might feel for Greek high culture from Umbricius' manifest distaste for actual Greeks. Appeals could be made, for example, to the juxtaposition of evident admiration for Hellenic accomplishments in rhetoric and philosophy on one hand with expressions of disdain for the triviality of contemporary Graeculi on the other in a work like Cicero's de Oratore $(1.47 ; 2.18-20) .{ }^{19}$ Such an approach misses the force of the joke about the opici ... mures ("barbarous mice") in the following line, however. 'O colonists to the aboriginal peoples of Campania, which was subsequently employed as a derogatory term for ignorant, Greekless Italians of all sorts (Strab. 5.4.3; Cato ap. Plin. NH 29.14) ${ }^{20}$ The philistine mice nibbling on the "divine songs" thus playfully evoke Umbricius' imagined confrontation between simple Romans and crafty, invasive Greeks, except that the

\footnotetext{
${ }^{19}$ Watts (1976) 98-100; Gruen (1992) 264-8; Isaac (2004) 389-93; also Serafini (1957) 357; Wardman (1976) 8-13. Cf. Cic. Q. Frat. 1.2.4, Plin. Ep. 8.24, also Dench (2005) 72-3; Boatwright (2012) 81-2.

${ }^{20}$ Cf. Thuc. 6.2.4; Gell. NA 2.21.4, 11.16.7; Fronto Ep. 1.9.8, 3.6 Hout; Dubuisson (1983); Dench (1995) 53, 77-9; (2005) 181.
} 
language used reflects the point of view of the self-assured and culturally superior foreign colonists. $^{21}$

In any event, the poor man's affiliation with Greek culture is not limited to his literary interests alone. Apart from the mice and the too-small bed (lectus, 203), everything in the list is a Greek object with a recognizably Greek name. The lack of bookshelves (foruli) may be

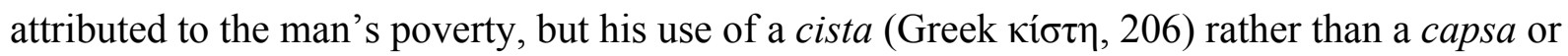
scrinium to hold his scrolls imparts a Hellenic flavor to the description of his furniture. ${ }^{22}$ More pointedly, the abacus ("sideboard," Greek $\alpha \beta \beta \xi$, 204) was a piece of furniture closely associated with the earliest waves of Hellenistic luxury to arrive in Rome. The historian L. Calpurnius Piso (fr. 34 Peter, ap. Plin. NH 34.14) recorded that this sort of table, along with larger monopodia and bronze-chased couches, was first introduced to Rome in $187 \mathrm{BCE}$ at the triumph of $\mathrm{Cn}$. Manlius Vulso, a commander notorious both for his rapacity and his indulgence of the soldiers' taste for Asiatic luxury. ${ }^{23}$ By a related turn of reasoning, C. Marius' use of a cantharus

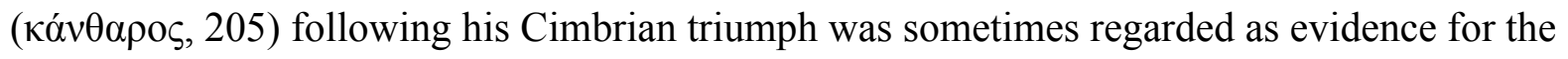
final victory of Greek decadence over native Roman virtue (Plin. NH 33.150, cf. Val. Max. $3.6 .6) .^{24}$

${ }^{21}$ For nibbling mice, cf. Callim. Aetia fr. 177; [Hom.] Bracch. 181-5; Anth. Pal. 6.302-3. Quintilian (Inst. 8.3.19) quotes as humorous a line from an unnamed poet about mice nibbling a (fabula?) pratexta, which was also kept in a cista.

${ }^{22}$ Weise (1964) 199. Cf. Courtney (1980) 182.

${ }^{23}$ Cf. Plb. 21.34-6, 43-4; Liv. 39.6.3-7.5; Harris (1979) 223-5; Boatwright (2012) 76; pace Gruen (1992) 106-7. See also Cic. Verr. 2.4.57.

${ }^{24}$ Mayor (1872) 204; cf. Gruen (1992) 268-9. For cantharus and other Greek cup types in Latin, see Macrob. Sat. 5.21; Weise (1964) 174-5. 
The cantharus of the apartment-dweller is small (parvulus), however, and the diminutive,

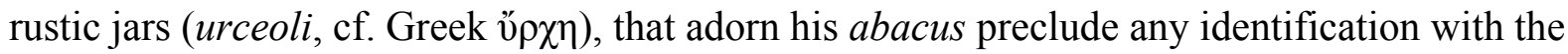
opulence of the great Roman generals of the past (even if we are dealing with a Cordus here). In fact, the presence of these items in such a modest setting may be taken to reinforce a sense of the ubiquity of Greek culture in Rome. Earlier in the Satire, Umbricius rails against the humble Roman who wears trechedipna (“dinner shoes(?)," 67) and niceteria ("victory garlands") around his ceromatico ("mud-coated," 68) neck. In his comment on this passage, Miller calls attention to "the way in which traditional Latin terms are interwoven with rare Greek words ... to reproduce on the linguistic level what Umbricius claims is occurring on the social level. ${ }^{25}$ In fact, this kind of interweaving is common in Juvenal's work, and constituted a recognizable feature of Roman verse satire going back to Lucilius, from whose precedent only Horace is known to have demurred (Sat. 1.10.20-6). ${ }^{26}$

Linguists term this kind of bilingual admixture "code-switching," and emphasize the selfconscious nature of its application in ordinary discourse.$^{27}$ Code-switchers do not alternate languages out of carelessness or mere convenience, but do so deliberately in order to convey culturally specific messages to their audience. By this measure, the diction employed to describe the furnishings of Codrus' abode probably would not rise to the level of code-switching on its own. The embedding of Greek terms here is certainly less marked than that found in Umbricius'

\footnotetext{
${ }^{25}$ Miller (2005) 253.

${ }^{26}$ Cf. Hor. Sat. 1.9.78, with Miller (2005) 165. Thiel (1901); Rudd (1986) 162-92; Rimell (2005) 86.

27 Gumperz (1982) 59-99; Scotton (1988). For Latin code-switching, see esp. Swain (2002); Adams (2003) 19-27, 297-305.
} 
attack on foreign leisure paraphernalia earlier in the poem. And yet, precisely because the speaker has already emphasized the exoticism and ridiculousness of Greek terminology in a previous diatribe, the reader becomes alert to the speaker's use of Graecisms, and thus more likely to pick up on the imported quality of the better-established loan words that make up the list of Codrus' possessions. As this relatively banal account of Hellenization passes without explicit hostile comment from Umbricius, the underlying contradiction between his rejection of Greek culture in certain contexts but (unwitting?) acceptance of it in others becomes more remarkable.

Even the marble of Codrus' Chiron (or, perhaps, his tabletop, 1. 205) can be interpreted as a symbol of the obliteration of local Roman character under a flood of Greek imports. ${ }^{28}$ Like

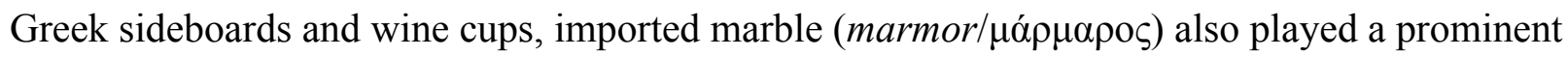
role in stock narratives linking Roman philhellenism with moral decline (e.g., Plin. NH 36.48). ${ }^{29}$ Elsewhere in the Satires, Juvenal refers to luxurious villas roofed with "Greek marble, brought in from far away" (Graecis longeque petitis / marmoribus, 14.89-90). This alien quality is explicitly invoked in the opening lines of Satire 3, in which the narrator describes the precinct of Egeria, where he has come to bid Umbricius farewell, and laments how the natural beauty of the place has been spoiled by the "artificial grottoes" (speluncas / dissimiles veris, 17-18) that

${ }^{28}$ See n. 3 above. Citing Markland's unpublished notes on the text, Braund (2004) 182-3 prints centaurus recubans ab eodem marmore Chiron and translates, "a little centaur, Chiron, made from the same "marble'," with an explanatory note, "i.e., from earthenware, the same as the jugs." But the logical counterpart of a ceramic vessel would be a metal one, not marble. If emendation is necessary, we would do better to allow Codrus to own at least one genuine marble item.

${ }^{29}$ See also Weise (1964) $157-8$. 
have been constructed around the original spring. The spirit of the nymph (numen aquae) would feel closer, the narrator suggests, if there were still some grass around it, "and marbles had not intruded upon the native tufa" (nec ingenuum violarent marmora tofum, 20). ${ }^{30}$

In his description of Codrus' humble possessions, Umbricius appears to be insensitive to marble's foreign, invasive qualities. His ire is reserved instead for the nobles who ignore the poor man's suffering, but only come forward with gifts of marble (et iam accurrit qui marmora donet, 215) when a magnate like Assaracus (Asturicus?) loses his home to fire. The donations include Greek masterpieces by Euphranor and Polyclitus, ancient plunder from the temples of Asia minor, and a grand library, complete with bookcases (forulos, 219) and a figure of Minerva (rather than Chiron) to stand in the center. As the gifts of these self-dealing plutocrats evoke what was lost in the apartment fire in a different economic register, the reader's sympathy (and, we assume, that of the speaker) is drawn to the poor man, who is left "naked and begging in vain" (nudum et frustra rogantem, 210). ${ }^{31}$ It is important to notice that the pauper's lifestyle differs from the rich man's only in its modest scale, not in its susceptibility to Greek influence.

\section{Daedalus' City}

The undercurrent of class resentment in this account of the divergent fates of Codrus and Assaracus brings the reader back to the principal reason for Umbricius' departure from Rome.

\footnotetext{
${ }^{30}$ Adamietz (1972) 39-40; Fredericks (1973) 62-3; Braund (1996a) 176; Hardie (1998) 239-41; Larmour (2007) 196-9; Jenkyns (2013) 239-40.

${ }^{31}$ Serafini (1957) 321-2; Anderson (1970) 16; Jenkyns (2013) 63-4. Miller (2005) 264 notes the "ironic contrast" between Codrus' pathetic nudity and that of the nuda et candida signa presented to Assaracus (3.216).
} 
Umbricius repeatedly affiliates himself with the plight of the impoverished $(3.140-53,160-3$, 259-67). This alignment, which he shares with other Juvenalian personae (cf. 1.132-8, 7.59-62, 9.63-9), may ultimately contribute to the ambiguity of his position, insofar as the poor can also be construed as a target of satiric mockery. ${ }^{32}$ In Umbricius' case, the rationale for his departure from Rome begins from the premise that there is "no place for honorable talents in the city and no profit for hard work" (artibus ... honestis / nullus in urbe locus, nulla emolumenta laborum, 21-2). ${ }^{33}$ His moral integrity, which debars him from making a living as a sanitation engineer, undertaker, or gladiatorial impresario (29-40), also prevents him from obtaining the goodwill of a patron (41-57). This is how Greeks come into the discussion (58-61):

Quae nunc divitibus gens acceptissima nostris et quos praecipue fugiam, properabo fateri, nec pudor obstabit. non possum ferre, Quirites, 60 Graecam urbem ...

That race which is now so well received among our rich and which I principally flee, I will quickly state, and shame will not prevent me. I cannot endure, oh countrymen, a Greek city.

Several lines of derogatory abuse follow about Levantine Greeks, their lingua et mores, and especially the material culture they bring in their train (61-70, see below). Umbricius then comes

${ }^{32}$ Freudenburg (2001) 267-8. The point is spelled out explicitly in lines 152-3: nil habet infelix paupertas durius in se, / quam quod ridiculos homines facit ("unhappy poverty has nothing so harsh in itself but that it makes men laughable"). See also Moodie (2012) 103. As Rosen (2007) 9-12 explains, the topos of the impoverished satirist can be traced back to the Greek iambographic tradition.

${ }^{33}$ Adamietz (1972) 45-8. Cf. Verg. Aen. 3.393; Staley (2000) 87. 
to the core of his complaint against these immigrants: "They seek out the Esquiline and the hill named for its osier, where they become the hearts of great households and their masters," (Esquilias dictumque petunt a vimine collem, / viscera magnarum domuum dominique futuri, 712).

Once arrived in Rome, the Greeks make their way into the households and good graces of wealthy patrons, displacing supposedly honest Romans such as Umbricius. They are aided in this endeavor by their predisposition for acting (100: natio comoeda est), an ethnic characteristic that forms the basis of a good parasite's career. Specifically, these capabilities enable the Greeks to ingratiate themselves by means of baseless flattery and false empathy $(86-91,100-8) .{ }^{34}$ And yet, before Umbricius gets around to denouncing the ways in which deceptive Greeks go on to betray their patrons' trust (109-18), he reveals something about his own abilities: "we too may praise these things, but they are believed." (haec eadem licet et nobis laudare, sed illis / creditur, 923). Although Umbricius denounces the Greeks as vicious and deceitful interlopers, he appears to share their parasitic approach and perhaps even their base objectives. The only thing he professes to lack is their talent.

Umbricius' indignation about invading Greeks thus amounts to thinly veiled jealousy, coupled with a vain desire to counteract the perceived cultural advantages of the immigrant group by calling attention to their foreign origins (81-5):

horum ego non fugiam conchylia? me prior ille signabit fultusque toro meliore recumbet, advectus Romam quo pruna et cottana vento?

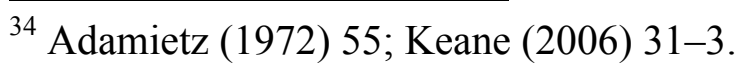


usque adeo nihil est quod nostra infantia caelum hausit Aventini baca nutrita Sabina?

Shouldn't I flee their pourpre? Will that man subscribe before me, and lie padded by a better couch, who came to Rome on the same wind that brought the plums and figs? Is it all for nothing that my youth breathed the Aventine's breeze and fed on a Sabine olive?

Once again, we encounter the marked use of different linguistic registers to convey a sense of cultural difference. The Greeks, together with the luxury they enjoy, are characterized by conchylia and imported fruits, while Umbricius identifies himself with the simple Sabine baca. ${ }^{35}$ This appeal to local origins, which Umbricius assumes should attract the affinity of a noble patron, lays bare the opportunistic nature of his exploitation of such terms. The irony, of course, is that in desiring a better seat at the banquet, this native-born Italian reveals his own interest in the imported sweetmeats of the rich man's table, and so at the same time distances himself from the idealized, rustic foodways that he uses to validate his claim of ethnic superiority. The paradoxical linkage of an appetite for decadent foods with indignation about luxurious dining, which runs throughout Juvenal's satiric discourse (cf. 5.24-48), thus provides further insight into the ambivalent nature of Umbricius' relationship with Greek culture. ${ }^{36}$

Umbricius' decision to abandon Rome is explicitly linked to his belief that he cannot compete with the Greeks who have monopolized the patronage that used to be available to

${ }^{35}$ Cf. Sil. Pun. 3.596: bellatrix gens bacifero nutrita Sabino; Mayor (1893) 191. For the opposition of Graecum with Romanum atque Sabinum, cf. Lucil. 88 Marx. On the Roman idealization of Sabine rusticity, see Dench (1995) 85-94.

${ }^{36}$ Gowers (1993) 218-19; Freudenburg (2001) 270-75; Rimell (2005) 85. 
Romans like himself. ${ }^{37}$ But what is it about the Greeks in particular that makes them so effective at obtaining, and holding onto, patronage at Rome? Umbricius' portrait of the Greek genius can be read as a hostile reinterpretation of Horace's aphorism about captured Greece taming the victor with its superior culture $(73-80):{ }^{38}$

ingenium velox, audacia perdita, sermo promptus et Isaeo torrentior. ede quid illum esse velis: quemvis hominem secum attulit ad nos. 75 grammaticus, rhetor, geometres, pictor, aliptes, augur, schoenobates, medicus, magus, omnia novit Graeculus esuriens: in caelum iusseris, ibit. in summa non Maurus erat neque Sarmata nec Thrax qui sumpsit pinnas, mediis sed natus Athenis. $\quad 80$

His mind is quick, his bravery tested, his speech ready and more flowing than Isaeus. Say what you want him to be: he has brought everyman along to us. Grammarian, rhetorician, geometer, painter, trainer, seer, ropewalker, doctor, wizard - he knows everything, the hungry little Greek: order him to take flight, he will go. In the end, it was not a Moor or Sarmatian or Thracian who put on wings, but one born in the heart of Athens.

37 3.119-22: non est Romano cuiquam locus hic, ubi regnat / Protogenes aliquis vel Diphilus aut Hermarchus, / qui gentis vitio numquam partitur amicum ("there is not any place here for a Roman, where reigns some Protogenes or Diphilus or Hermarchus, who according to the flaw of his race does not share a friend"); LaFleur (1975) 55.

${ }^{38}$ Hor. Ep. 2.1.156-7; Boatwright (2012) 66-7. See Isaac (2004) 225-6, 233 for other variations on the theme. 
Just as the description of the material culture that Syrian Greeks bring in their train underscores their exoticism (63-8), the piling up of Greek occupational vocabulary in the middle of this passage (76-7) draws attention to the foreign character of the "self-made" Graeculus. ${ }^{39}$ Such lists not only condition the reader to notice the Greek character of Codrus' possessions when they are inventoried later in the Satire, they also reveal something about the inherent instability of this sort of urbane antihellenism. The logic of code-switching begins to overwhelm the purposes to which Umbricius ostensibly employs it, as the ability to invoke these terms, even in disapproval, betrays close familiarity. By deviating so often from Latin into Greek, Umbricius cannot help but implicate himself in the culture he claims to be rejecting. ${ }^{40}$

What are we to make of these inconsistencies? To the sympathetic reader, "Umbricius' intense, irrational hatred of the Greeks is an unfortunate response to the serious economic threat they pose for him." ${ }^{, 41}$ The point is not simply that Greeks are cunning, or that they are false friends to their patrons. It is that their cunning seems to provide them with advantages in acquiring the patronage of a philhellenic Roman elite. ${ }^{42}$ Framed in these terms, the situation is analogous to what some social anthropologists have observed about the manipulation of ethnic loyalties as a means of mobilizing solidarity among populations in competition for scarce

\footnotetext{
${ }^{39}$ Wehrle (1992) 78; Braund (1996a) 187; also Thiel (1901) 50-1.

${ }^{40}$ See above, n. 27; Kaimio (1979) 297-315. Cf. Suet. Tib. 71, with Wallace-Hadrill (1998) 83, on the policing of Graecisms in Tiberian decrees; also Sedley (1999) on the anxieties expressed by Lucretius (1.136-45, cf. Cic. Acad. 1.24-6) about the use of Greek philosophical language in his Latin epic.

${ }^{41}$ Sarkissian (1991) 255.

42 Sherwin-White (1967) 71-6. See also Anderson (1964) 145; LaFleur (1976) 398-9, 425-7; Watts (1976) 96-7; Freulund Jensen (1986) 90; Braund (1989) 30.
} 
resources. ${ }^{43}$ Rightly rejecting an older, essentializing concept of ethnicity, this "instrumentalist" approach recognizes the flexibility of ethnic identities, particularly in respect to the various markers (linguistic, cultural, physiognomic) used in their construction. The deployment of these markers can thus be set within the context of various personal strategies for negotiating one's relationship with society at large. Such an approach seems to fit nicely with the inconsistencies of Umbricius' attitude to Greek culture: he can Hellenize when he chooses to, but becomes an unspoiled, xenophobic Roman when it serves his interests.

These are important insights, but it must also be noted that there are limits to how well an instrumentalist explanation fits the quirks of Umbricius' persona, let alone the social realities of Roman Italy. In modern contexts, this type of situational ethnicism is particularly associated with cosmopolitan urban settings not dissimilar from the Rome that Umbricius wants to leave behind. ${ }^{44}$ And yet, a consideration of ancient demography casts doubt on Umbricius' assumption that his problems could be solved by moving to a small town. Whereas the persona of this Satire focuses on the arrival of free Greeks seeking to make their fortune in the metropole, Rome's slave system was probably more significant as a driving force in the movement of populations within the empire, and the cumulative impact of this process of forced migration on the "ethnic" profile of the capitol would not have differed significantly from that experienced in other parts of Italy. ${ }^{45}$ The monuments of freedmen, particularly those of Augustales, attest to the success that

\footnotetext{
${ }^{43}$ Wallerstein (1960); Cohen (1969) 183-201; see also Peel (1989); Eriksen (2010) 53-69.

${ }^{44}$ Cohen (1974); Eriksen (2010) 23-6. Cf. Park (1950); Glazer and Moynihan (1963).

${ }^{45}$ Harris (1980) 125-8; Scheidel (2005), (2011); Boatwright (2012) 24-7.
} 
some of these foreigners had in gaining wealth and social acceptance in the towns of Italy. ${ }^{46}$ Unlike white Americans who segregated themselves by relocating to suburban enclaves in the mid-twentieth century, Umbricius would not have found the countryside any more "Roman" than the city he has decided to abandon. ${ }^{47}$

More to the point, Umbricius' chosen destination is especially difficult to reconcile with his professed inability to tolerate a "Greek city" (Graecam urbem, 61). ${ }^{48}$ Although this homebred Italian praises the simplicity of Sabellan dining habits (85) and the egalitarian fashions of rural theater-goers (168-79), he is not planning to relocate to the turnip farm of M. Curius Dentatus or some other place associated with the traditional virtues of rustic simplicity. ${ }^{49}$ Rather, he is going to Cumae, a site of luxury villas on the Campanian coast, where the vacationing elite continued those practices - including their patronage of Greek intellectuals - that Umbricius claims to find so troubling at Rome. ${ }^{50}$ Although the demographic profile of imperial-era Cumae cannot be known with any precision, one need not look very far into the epigraphic record to find such Greek cognomina as Zoticus, Marcion, and Stephanus attested there (CIL 10.3684, 3692, $3699=I L S 7299,3170,4174)$. It was not so different, in other words, from Umbricius' Rome,

${ }^{46}$ Duthoy (1978); Mouritsen (2011) 248-61. Cumaean Augustales: CIL 10.3701, AE 197190. See also Garnsey (1975); Dench (2005) 207-10.

${ }^{47}$ Cf. Jackson (1985) 190-230; Sugrue (1996).

${ }^{48}$ Cf. Tac. Ann. 15.33.2, of Naples; also Petr. 81, with Bagnani (1954) 82 n. 37. Courtney (1980) 164 and Braund (1996a) 56, (2004) 170-1 attempt to solve the problem by capitalizing Vrbem, thus confining the reference to Rome itself.

${ }^{49}$ Cic. Sen. 55; Plut. Cat mai. 2.1-2; Juv. 11.78-80; Serafini (1957) 147; Braund (1989) 27; Freudenburg (2001) 268-9; Jenkyns (2013) 68.

${ }^{50}$ D'Arms (1970) 142-52. Cumaean villas are discussed in Sen. Ep. 55.2-7, Tac. Ann. 16.19.1. Cf. Juv. 11.46-9 (of Baiae). 
where names like Protogenes, Diphilus and Hermarchus characterize competitors for patronage (119-20), and the actors Antiochus, Stratocles, Demetrius and Haemon embody the Greek talent for convincing transvestism (98-9). ${ }^{51}$ Perhaps we should make sense of the joke from the opening lines of the Satire about Umbricius providing the famous Sibyl with "one citizen" (unum civem donare Sibyllae, 1. 3) in this context: i.e., he will be the only Roman in a distinctively Greek enclave. $^{52}$

Although taken over by Samnites in the fifth century BCE and subsequently granted Roman citizenship, Cumae kept its Greek character and remained famous as the first Greek colony established on the Italian mainland. ${ }^{53}$ Indeed, this fact is hinted at in the punchline of the above-quoted diatribe about Greek craftiness. According to the legend related by Vergil (Aen. 6.14-33), Cumae's temple of Apollo was originally established by none other than Daedalus, whose wings (pinnas, 80) Umbricius ridicules as the epitome of Greek volatility. ${ }^{54}$ The reader is clearly meant to notice the contradiction, because Umbricius also speaks of his plan to go "where

\footnotetext{
${ }^{51}$ Jones (2007) 56. While Gordon (1924) 103-6 has pointed out that a freedman's Greek name need not correlate with "genuine" Greek origins (cf. Solin (1971) 121-35, Webster (2010) 50-1), nomenclature appears to be one of Umbricius' favorite criteria for defining Greekness (Codrus aside). Note how different his concerns are from the racist anxieties of Frank (1916) (on which see Dench (2005) 227-9).

${ }^{52}$ Braund (1990) 505; cf. Hardie (1998) 249. The line has sometimes been taken, without corroboration (e.g., D'Arms (1970) 163; Courtney (1980) 155-6), as a sign of Cumae's decline in Juvenal's day. Cf. 3.2: vacuis ... Cumis, ("peaceful/empty Cumae"). It was, in fact, a thriving city: Fears (1975); LaFleur (1976) 403-5. Note also Frederiksen (1984) 75-6 on the Sibyl's status as a characteristically Greek institution.

${ }^{53}$ Livy 8.22.6; Strab. 5.4.4; Frederiksen (1984) 54-5, 68-77, 139.

${ }^{54}$ Cf. Ov. Met. 8.188-95; Staley (2000) 96-7.
} 
Daedalus took off his tired wings" (fatigatas ubi Daedalus exuit alas, 25) at the beginning of his speech. ${ }^{55}$ While Cumae's smaller size might offer relief from some inconveniences of urban living, it remains an unlikely refuge for someone who truly could not stand Greeks or Greek culture.

Cumae's prominence in the Aeneid might be said to cut both ways, of course. Staley stresses the intertextual connection with Vergil in his defense of Umbricius' seemingly incongruous destination, arguing that Umbricius "chooses it not because of its Greek associations, but because of its proto-Roman ones. ${ }^{, 56}$ If so, this would mean that Umbricius has misunderstood the implications of his source text, in which one of the more obvious lessons seems to be that Daedalus and Aeneas, as refugees who land at Cumae, shared a similar fate. ${ }^{57}$ The invocation of Vergil necessarily invites the reader to reflect on the extent to which Greek culture, much like the Homeric nekyia that forms the model for Aeneid 6 as a whole, had become intertwined with Roman identity, to an extent that these connections could even be said to predate the city's foundation.

\section{Syrians, Achaei and the faex Romuli}

For the most part, Umbricius paints with a broad brush. His graecophobia encompasses persons from a large swath of the Eastern Mediterranean, stretching from Daedalus' Athens to Tarsus in

55 LaFleur (1976) 401-2; Winkler (1983) 222; Wehrle (1992) 68. Anderson (1957) 67; Fredericks (1972); Rimell (2005) 92 and Jones (2007) 85 also comment on the paradox.

${ }^{56}$ Staley (2000) 90.

${ }^{57}$ Pöschl (1962) 150; Putnam (1998) 76. 
Cilicia (a place identified with another set of mythical wings, those of the Pegasus). ${ }^{58}$ The list of possible origins for the parasites invading the great households of Rome (69-70) begins in the very center of mainland Greece (Sicyon) and progresses through Macedonia (Amydon), across the Aegean (Andros and Samos) to the Graeco-Carian cities of Anatolia (Tralles and Alabanda). ${ }^{59}$

Umbricius' denunciation of Greek immigrants from such far-flung shores is marked by an important qualification, however (61-6):

- quamvis quota portio faecis Achaei?

iam pridem Syrus in Tiberim defluxit Orontes

et linguam et mores et cum tibicine chordas

obliquas nec non gentilia tympana secum

vexit et ad circum iussas prostare puellas.

ite, quibus grata est picta lupa barbara mitra.

... and yet, what part of these dregs are Achaeans? For a while now Syrian

Orontes has disgorged into the Tiber, bringing along its language and customs and the slanted harps with flautists, not to mention its national drums and those girls pressed into streetwalking at the Circus. Go there, if you like a barbaric whore in an embroidered turban.

58 3.117-18: ripa nutritus in illa / ad quam Gorgonei delapsa est pinna caballi.. Following Teuffel (1865), Willis (1997) 27 marks these verses as an interpolation: cf. Housman (1931) xxxi-xxxii; Maas (1958) 14-15. For Pegasus' association with Tarsus, see Steph. Byz. Ethn. 605-6 Meineke.

${ }^{59}$ Adamietz (1972) 49. 
This evocation of a noisy cult procession emanating from the Orontes diverts Umbricius' antihellenic tirade into a separate, seemingly irrelevant debate about the nature of Greek cultural identity. Although the musical instruments they carry are identified as foreign through the use of Greek vocabulary, Umbricius makes it clear that these people are really Syrian, rather than Greek, in their language and culture (et linguam et mores). In so doing, he adopts the point of view of Greeks from the heartland - i.e., the Roman province of Achaea-who claimed to possess a "pure" form of Hellenism, based on ethnic bonds of blood descent, which could be regarded as superior to the (more easily hybridized) "common culture" of Hellenism that had flourished in places like Antioch since the time of the Seleucids. ${ }^{60}$

In addition to their tastes in music, the exoticism of the Syrians is heightened by the "barbaric whore in an embroidered turban" (picta lupa barbara mitra, 66) with which this list culminates - an apparent reference to sacred prostitution, that imaginary practice frequently ascribed by classical authors to the religious centers of Syria and other civilizations of the ancient Near East (Lucian Syr. D. 6; cf. Hdt. 1.199).${ }^{61}$ And yet, Umbricius does not actually attack the Syrians for introducing prostitutes to Rome; he merely ridicules them because their girls are cheap and unfashionable, joking with his interlocutor about the prospect of patronizing such a lupa. This equivocation provides grist for yet another joke about Umbricius' not-so-secret

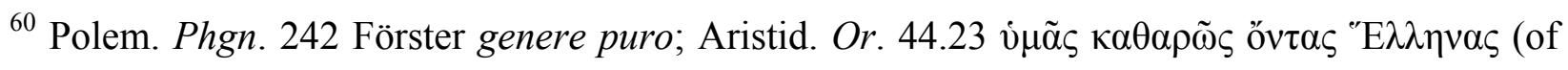
the Rhodians); cf. Dio Or. 48.8 (of Prusa); Plin. Ep. 8.24.2 illam veram et meram Graeciam; Isaac (2004) 111-14; Dench (2005) 260-1. “Common culture:” Isoc. Pan. 50; Hdt. 8.144.1-3; Konstan (2001) 32-4; Hall (2002) 189-225; cf. Swain (1996) 33-42; Romeo (2002). The arbitrariness of Umbricius' distinction passes without comment too often in modern scholarship on the Satire, e.g., Miller (2005) 253; Hooley (2007) 117.

${ }^{61}$ See esp. Budin (2008). 
affinity for the Greek things he says he cannot tolerate, when he subsequently complains about the wealth of slaves who are able to purchase sexual favors from well-born Roman ladies, "but, when the face of some veiled slut tempts you, you pause and scruple over leading Chione down from her high seat" (134-6: at tu, / cum tibi vestiti facies scorti placet, haeres / et dubitas alta Chionen deducere sella). The implied hierarchy of desirability is as much about price as ethnicity, but it is clear that the Greek-named (but fair complexioned?) Chione will do just fine for a man of Umbricius' appetites. ${ }^{62}$

Despite the caveat about barbaric Syrians, Umbricius nevertheless implies that these people (and things) are responsible for Rome's transformation into a "Greek city." Along with the Achaei and any "pure" Greeks from Asia Minor, the effluvium of the Orontes comprises part of the same faex that he sees as taking over Rome. After all, many of those Syrians would be capable of "passing" as Greeks in education and culture upon arrival in the capitol. Compare Meleager, the writer of Greek epigrams who gives his birthplace as "Attic Gadara," while stressing the unity of the human race (Anth. Pal. 7.417), or, more relevant, Lucian of Samosata, whose Salaried Gentleman offers an oblique rejoinder to Umbricius' attacks on the behavior of Greek intellectuals at Rome (see esp. Merc. Cond. 27, 35, 39). ${ }^{63}$ The sophist Isaeus, whose impromptu eloquence Umbricius invokes as the standard of Greek loquacity (74), was, in fact, an

${ }^{62}$ Cf. Jones (2007) 40-1.

${ }^{63}$ Meleager: Galinsky (1992) 129-30; Isaac (2011) 494. Lucian: Sherwin-White (1967) 62-71; Swain (1996) 298-329; Jenkyns (2013) 69. Cf. Konstan (2001) 39-40 on the cosmopolitan ideal of contemporary philosophical discourse. On the complexity of identity in Hellenistic Syria generally, see Isaac (2004) 335-8. Note also the parallel (and better documented) case of Ptolemaic Egypt: Thompson (2001). 
Assyrian (Philostr. VS 512). ${ }^{64}$ Umbricius' abortive attempt to acknowledge the internal divisions within a population that could just as easily be lumped together as an undifferentiated gens (58) of hungry Graeculi calls the reader's attention to the ways in which ethnic identity is always contingent upon one's point of view. ${ }^{65}$ Even as he goes on to put a hostile spin on this distinction in his attack on the Athenian-born Daedalus (79-80), the significance that Umbricius gives to these divisions suggests the extent to which his own, ostensibly "Roman" position on these matters has been assimilated to the perspective of a certain kind of Greek. He may have nothing but contempt for the Greeks, but it is the contempt of a connoisseur.

The ambivalent status of Syrian Greeks in the Satire also raises a more fundamental question about the nature of Roman identity itself. As much as Umbricius wants to assert the importance of his local origins, Romans did not have access to the sort of claims about ethnic "purity" that the Hellenes might use to police the boundaries of their identity. ${ }^{66}$ As the experience of Paul of Tarsus reminds us, Roman citizenship was tied neither to place nor culture. ${ }^{67}$ Unlike autochthonous Athens, Rome's civic mythology was that of a city founded by shepherds and outcasts and subsequently augmented by immigrants from all over Italy. ${ }^{68}$ As has

${ }^{64}$ More likely than the Athenian logographer; cf. Plin. Ep. 2.3.1-4, Philostr. VS 514; Ferguson (1987) 121; Smith (1997); see also Sherwin-White (1967) 77.

${ }^{65}$ Moerman (1965).

${ }^{66}$ Isaac (2004) 134; Dench (2005) 246-56; Boatwright (2012) 18.

${ }^{67}$ Acts 22:23-29; Sherwin-White (1973) 237-74; Hall (2002) 22-3; Dench (2005) 93-107. Cf. Konstan (2001) 30 on "civic identity, which is juridical rather than essentialist."

${ }^{68}$ Dench (2005) 1-5, 152-7; Boatwright (2012) 6-8; cf. Hall (2002) 203-5; Isaac (2004) 11424. 
already been noted, Aeneas, like Daedalus before him, was a refugee when he arrived on Italian soil.

Umbricius, with his taste for Sabine olives (3.85) and a name that could suggest Etruscan origins (cf. Plin. NH. 10.19), ought to appreciate these nuances, but somehow fails to do so. ${ }^{69}$ When he mocks the lupa (n.b.: not moecha) barbara that the Syrian pimps offer in the arcades of the Circus Maximus, his phrasing brings to mind the "she-wolf" of Rome's foundation narrative, who nursed Romulus and Remus in the shadow of the Palatine, at a spot not far from the circus valley (Livy 1.4.6-7; cf. Dion. Hal. AR 1.79.8). Along similar lines, his description of the influx of Greek foreigners as "dregs" (faex) may recall Cicero's reference to the faex Romuli (Att. 2.1.8; cf. Luc. 7.405), a phrase Dench interprets as a possible allusion to the debased origins of Rome's earliest inhabitants. ${ }^{70}$ What the Syrians are in Umbricius' eyes—despised, barbarous, prostitutes-the Romans were from the beginning. ${ }^{71}$

${ }^{69}$ Olive: Jenkyns (2013) 270; see also Hardie (1998) 248, on the caelum ... Aventini of Umbricius' youth (3.84-5). Name: LaFleur (1976) 386-7; Ferguson (1987) 235; Braund (1990) 505. Many scholars regard Umbricius as a speaking name, stressing its derivation from umbra ("shade," but also "hanger-on"): cf. Motto and Clark (1965) 275; Baldwin (1972) 101; Staley (2000) 87-9; Freudenburg (2001) 267; Jones (2007) 86; Hooley (2007) 117-18.

${ }^{70}$ Dench (2005) 16. Cf. Jenkyns (2013) 164-5.

${ }^{71} \mathrm{Cf}$. the concluding lines in the critique of noble lineages, Juv. 8.274-5: maiorum primus, quisquis fuit ille, tuorum / aut pastor fuit aut illud quod dicere nolo ("your first ancestor, whoever he was, was either a shepherd or that which I would rather not say"). 


\section{Conclusion: Umbricius' Shame}

The approach to Juvenal's third Satire developed here depends upon the reader's acknowledgement of the substantial distance between the position of Umbricius' persona and that of the text's (implied) author. Although Umbricius ostensibly gives voice to the resentment and outrage of a typical Roman graecophobe, his arguments actually expose the callowness and internal contradictions of this sort of ethnic prejudice. He cannot stand a Greek city, but is headed for Cumae. He attacks Greeks for their insincerity, but is equally manipulative when given the chance. He disapproves of Greek culture, but reveals a deep appreciation of it. He despises immigrants and foreigners, but expresses sympathy (perhaps) for a man with the Greek name Codrus. Taken together, these contradictions cannot be ignored or emended away, and must be regarded as part of the underlying message of the work as a whole.

As an exercise in literary criticism, this interpretation of the satire is not entirely new; many of the observations on which it is based have been made before by others. Indeed, by focusing on Umbricius' xenophobia, I have passed over a number of additional contradictions that have been revealed about this persona. ${ }^{72}$ To return to the textual issue with which this article began, one might almost say that it is surprising that scholars like Braund and Miller, who are otherwise so attentive to the ways in which the poet distances himself from the speaker he constructs in each Satire, have nevertheless persisted in printing Cordo ... Cordus in their

editions of the text, thereby depriving Umbricius of another potentially striking inconsistency. ${ }^{73}$

\footnotetext{
${ }^{72}$ See Winkler (1983) 220-3; Freulund Jensen (1986) 191-5; Wehrle (1992) 69; Braund (1996a) 233.

${ }^{73}$ Braund (1996a) 2, 233; Miller (2005) 2-6, 248.
} 
But the stakes involved are higher: acknowledgement that the poor apartment-dweller with whom Umbricius aligns himself might have been a Greek invites us to look beyond the narrow confines of the Satire as a rhetorical construct and consider the nature of the social world in which this persona pretends to situate himself. ${ }^{74}$ The point is not simply that Umbricius is a doctus ineptus, who may be misguided or insincere in his efforts to blame foreigners for his own shortcomings. Insofar as his hatred of the Greeks is rooted in instrumental concerns, he presents a deeply distorted account of the impact of immigration on Roman society. If Willis' reading of the name is correct, Codrus' fate forces the reader to confront the fact that many of those immigrants were at least as miserable and powerless as Umbricius pretends to be. Rather than usurping the Roman's rightful place in his native city, a Greek is revealed to be the victim of its gravest hazards.

A similar observation can be made about the Jews, whose presence in the grove of Egeria is noted by the narrator in the opening lines of the satire (3.14-16, cf. 8.160). At first blush, the presence of a group notorious for their exotic superstitions (cf. Tac. Hist. 5.4-5; Juv. 14.96-106) in a place where the principles of Roman religion were revealed to Numa seems to confirm Umbricius' worst fears about the city's transformation in the face of immigration from the East. ${ }^{75}$ On the other hand, the seemingly dismissive reference to the "baskets and hay" that

${ }^{74}$ Cf. Keane (2006) 8-9, on the concept of the "satirist figure," whose postures are embedded in a social context, as opposed to the more narrowly defined object of persona theory. Note also Freudenburg (2001) 270, of Trebius' humiliation at the banquet: "Dare we take such a cruel, comical view of the poor man's plight in Rome, and thus risk being caught reclining in Virro's high seat, hosting a sadistic feast? Or do we see his show as tragic and true, an honest man's honest complaint about the way things 'really are' in Juvenal's Rome?"

${ }^{75}$ Larmour (2007) 199-201; Boatwright (2012) 157. 
comprise their furniture (cophinus fenumque supellex, 14) also brings the poverty of this Jewish encampment to the reader's attention. ${ }^{76}$ The narrator goes on to mention the special payment (mercedem, 15) that Jews were required to make to the Roman treasury before describing the grove itself as "begging" (mendicat silva, 16), in obvious metonymy for its residents. ${ }^{77}$

Not only does the narrator's description of the abjection he sees outside the porta Capena provide a revealing context in which to assess Umbricius' complaints about his own inability to make a living in Rome, it also conditions the reader's reaction when these poor immigrants reappear in Umbricius' speech, this time as the victims—or, rather, the intended victims —of violence. According to Umbricius, walking home after dark puts one in danger of being attacked by a thug who insults his prey by asking, "where have you settled? In what synagogue will I find you?" (296: ubi consistas? in qua te quaero proseucha?) before beating him up. ${ }^{78}$ By putting these words in the mouth of a brutal bully, Umbricius comes remarkably close to aligning

${ }^{76}$ Courtney (1980) 158; Braund (1996a) 177; Miller (2005) 250 all overlook the obvious interpretation of this line as a reference to humble bedding in favor of an elaborate theory that hay-lined baskets were used to keep food warm for the Sabbath. Cf. Adamietz (1972) 41 for an even more fanciful explanation.

${ }^{77}$ See esp. Goodman (1989). Braund (1996a) 177 and Miller (2005) 250 construe mercedem as a rent paid by the Jews for the privilege of using the grove, rather than as the tax they paid into the fiscus Iudaicus, but see Courtney (1980) 158-9. For begging Jews, cf. Juv. 6.543, Mart. 12.57.13.

${ }^{78}$ The aggressor characterizes his (Jewish) victim as poor through his description of the meal he has eaten (aceto ... conche ... sectile porrum ... elixi vervecis labra, 292-4) and of his host as a cobbler (sutor, 294): Braund (1996a) 224; Moodie (2012) 106-7. 
himself with the targets of the kind of xenophobia that he typically directs at others. ${ }^{79}$ If the supreme indignity is to be mistaken for a Jewish immigrant in Rome, it does not take a great deal of empathy to realize how much harder it must have been to be one.

Some readers may still be wondering what, if anything, this line of interpretation tells us about the nature of ethnic prejudice in Rome during the second century CE. That question does not have an easy answer. The most obvious point to make is that we must be extremely cautious about accepting anything Umbricius says at face value. Although few scholars today would embrace the conflation of author and satiric personae that lurks behind Balsdon's claim that "Juvenal was an unrepentant xenophobe; Greeks, Syrians, Egyptians, Jews- he hated them all," the impulse among cultural historians to take what these personae say seriously remains strong. ${ }^{80}$ In Isaac's magisterial study of the Classical origins of racist ideologies, for example, despite attentive citations of work by Anderson and Henderson on persona theory, the author nevertheless concludes that "satire may be used as a reliable reflection of contemporary readers' perception of their social environment" and that Umbricius' anti-Greek tirade "represents the perspective of some Romans, presumably that of typically querulous citizens without wealth." ${ }^{\prime 11}$ As I hope to have shown, this is a problematic approach to take.

I do not mean to dispute the fact that ethnic hostility and xenophobia were facts of life in imperial Rome. Undoubtedly many Romans, like Umbricius, were jealous of the successful Greeks in their midst and employed the language of ethnic difference as a means of channeling

\footnotetext{
${ }^{79}$ Keane (2006) 65-6. See also Moodie (2012), who identifies the bully as a satirist figure, used to provide metapoetic comment on the instability of Umbricius' persona.

${ }^{80}$ Balsdon (1979) 14.

${ }^{81}$ Isaac (2004) 42, 232.
} 
their frustration, just as social anthropologists would expect them to do. Adopting a different satiric standpoint, Lucian describes what it was like to be on the receiving end of such resentment (Merc. Cond. 17, 40-41). But how many of these "querulous" Romans would have seen Cumae as a refuge from their problems, if they ever considered leaving Rome in the first place? Whatever its basis in reality, the incongruity of Umbricius' position is no more faithful a reflection of contemporary attitudes than his description of the city as "held up by slender props" (193: urbem ... tenui tibicine fultam) is an accurate guide to Roman construction techniques. ${ }^{82}$ As much as we may wish to identify Umbricius' use of Greek terms as a failure of what Barth calls “boundary maintenance,” such lapses reflect a literary, rather than a sociological, construct. ${ }^{83}$ Although the prejudices of this persona may have had an analogue in the views of some contemporary readers, what we read in Juvenal's Satire is nevertheless a deliberate distortion of those views. $^{84}$

The more interesting, yet more difficult, issue is what significance we should ascribe to this distortion. Might we see in the poet's subtle mockery of Umbricius the origins not of racism, but of tolerance? In posing this question, I do not seek to reestablish Juvenal as some sort of moral crusader, who sought to challenge the xenophobia of his fellow Romans by exposing the fallacies and base motivations that lurk behind their prejudices. Certainly the principal lesson of persona theory, as well as other more recent approaches to satire, is that moral certainty itself

\footnotetext{
${ }^{82}$ Rimell (2005) 85; cf. Braund (1989) 32-4; Laurence (1997).

${ }^{83}$ Barth (1969) 11.

${ }^{84}$ Hooley (2007) 137: “[contemporary prejudices] were attitudes in place already, registers of a great many Romans' view of the world; these elements of their imagination become elements of Juvenal's art."
} 
constitutes the primary target for this kind of discourse. ${ }^{85}$ I would nevertheless like to raise the possibility that the ideas at play in this satire might be significant in their own right. To wit: so long as we assume that the problems that have been identified with Umbricius' graecophobia derive from Juvenal's authorial design rather than from modern readers' subjective interactions with his text, it stands to reason that these problems in themselves reveal something about how some Romans might have thought about these issues. ${ }^{86}$ Beyond demonstrating, once again, that ethnic prejudice is an inherently unstable construct, this Satire suggests that perceptive Romans were themselves aware of that instability. Regardless of the abdication of responsibility that accompanies a satirist who hides behind the personae he creates, the audience's ability to recognize the comic inconsistencies of Umbricius' position implies a corollary ability to criticize (or at least acknowledge criticisms of) his point of view.

There are reasons to doubt this proposition, not the least of which is Archie Bunker, the "loveable bigot" at the heart of the enormously popular 1970s American sitcom All in the Family. Confronted with criticism that this program effectively condoned racism by presenting a form of "sanitized bigotry," its creator insisted that the main character's views were, in fact, the object of the show's humor: "Archie at best will work out some kind of convoluted logic to make a point. But it is always foolish. Totally foolish." ${ }^{, 87}$ Surveys revealed that prejudiced viewers were less likely to be in on the joke, however, and that those viewers were also more likely to

\footnotetext{
${ }^{85}$ Kernan (1959) 24-5; Hooley (2007) 139; Rosen (2007) 222-3 and passim; (2012).

${ }^{86}$ Cf. Highet's critique of the persona approach (1974) 329-30: "it is far from clear why these tensions, or inconsistencies, should not be inherent in the poet Juvenal himself, rather than be created by him for a fictional 'satirist'."

${ }^{87}$ Lear (1971).
} 
watch All in the Family, presumably because they identified with the opinions of the character they perceived to be its hero. ${ }^{88}$ If it sounds invidious to compare the readers of Roman verse satire with the viewers of an American television comedy, Juvenal's reputation as a serious moralist among Christian writers from late antiquity up to the modern age can be used to suggest the salience of the concept of selective perception for the present discussion. ${ }^{89}$ For satire to work as a vehicle for social criticism, the audience must first be prepared to recognize its real target.

We might take some encouragement, however, from the fact that Umbricius prefaces his admission of indignant anti-Hellenism with the bluster that "shame will not prevent" him from naming the objects of his displeasure (60: nec pudor obstabit). This reference to pudor suggests that such views were not widely held, at least among the fashionable circles that made up Juvenal's ideal audience. $^{90}$ It is important to remember what Umbricius does not tell us about contemporary Rome, such as the fact that Greeks were not just making inroads as parasites, but were also rising through the senate in increasing numbers to become consuls and influential members of the Imperial court. ${ }^{91}$ The emperor Hadrian was himself a committed philhellene, so

\footnotetext{
${ }^{88}$ Vidmar and Rokeach (1974).

${ }^{89}$ Wiesen (1963) 440-7; Iddeng (2000) 124-7. See, e.g., Augustine, Ep. 138.16 (quoting Juv.
} 6.287-96) and Dante, Purgatorio 22.14, where Juvenal is among quei c'hanno a giustizia lor disiro. Note also Highet (1954) 72: "Juvenal is therefore not venting merely a personal prejudice or the spite of a disappointed competitor. His words reflect a fact, and voice a feeling, which were deeply implicated in the life of the Roman empire, and it would not be too much to say that here once again he has put his finger on one of the causes which brought the empire to its collapse."

${ }^{90}$ On pudor as a key element of the Roman concept of the socially constituted self, see Kaster (2005) 28-65.

${ }^{91}$ Syme (1960) 13-19; Boatwright (2012) 87. 
much so that as a youth he was referred to (jokingly?) as a Graeculus (HA Hadr. 1.5). ${ }^{92}$ Such people may well have been prepared to laugh at a character like Umbricius, but would they have ever worried, as he seems to do, about the plight of an impoverished Codrus?

\section{WORKS CITED}

Adamietz, Joachim. 1972. Untersuchungen zu Juvenal. Weisbaden.

Adams, J. N. 2003. Bilingualism and the Latin Language. Cambridge.

Anderson, William S. 1955. Review of Highet 1954. CPh 50: 146-7.

—. 1957. "Studies in Book I of Juvenal.” YCS 15: 33-90. (= Essays on Roman Satire, 197254).

—. 1964. Anger in Juvenal and Seneca. University of California Publications in Classical Philology 19, pp. 127-96. Berkeley, CA. (= Essays on Roman Satire, 293-361).

—. 1970. "Lascivia vs. ira: Martial and Juvenal." CSCA 3: 1-34 (= Essays on Roman Satire, $362-95)$.

Bagnani, Gilbert. 1954. “Trimalchio.” Phoenix 8: 77-91.

Baldwin, Barry. 1972. “Three Characters in Juvenal.” CW 66: 101-4.

Balsdon, J. P. V. D. 1979. Romans and Aliens. Chapel Hill, NC.

Barth, Fredrik. 1969. “Introduction.” In Ethnic Groups and Boundaries: The Social Organization of Cultural Difference, edited by Fredrik Barth, pp. 9-38. Boston.

Boatwright, Mary T. 1987. Hadrian and the City of Rome. Princeton, NJ.

92 Boatwright (1987) 201-12; (2012) 73. 
- 2012. Peoples of the Roman World. Cambridge.

Braund, Susanna M. 1989. "City and Country in Roman Satire.” In Satire and Society in Ancient Rome, edited by S.M. Braund, pp. 23-47. Exeter.

—. 1990. "Umbricius and the Frogs (Juvenal, Sat. 3.44-5)." CQ 40: 502-6.

_. 1996a. Juvenal. Satires Book I. Cambridge.

_. 1996b. The Roman Satirists and Their Masks. London.

—. 2004. Juvenal and Persius. Loeb Classical Library 91. Cambridge, MA.

Budin, Stephanie L. 2008. The Myth of Sacred Prostitution in Antiquity. Cambridge.

Clausen, Wendell V. [1959]1992. A. Persi Flacci et D. Iuni Iuvenalis Saturae. 2nd edn. Oxford.

Cohen, Abner. 1969. Custom and Politics in Urban Africa. A Study of Hausa Migrants in Yoruba Towns. Berkeley, CA.

—. 1974. "Introduction: The Lesson of Ethnicity." In Urban Ethnicity, edited by Abner Cohen, pp. ix-xxiv. London.

Courtney, Edward. 1980. A Commentary on the Satires of Juvenal. London.

D’Arms, John H. 1970. Romans on the Bay of Naples. Cambridge, MA.

Dench, Emma. 1995. From Barbarians to New Men: Greek, Roman, and Modern Perceptions of Peoples from the Central Apennines. Oxford.

—.2005. Romulus' Asylum: Roman Identities from the Age of Alexander to the Age of Hadrian. Oxford.

Dubuisson, Michel. 1983. “Les opici: Osques, Occidentaux ou Barbares?” Latomus 42: 522-45.

Duthoy, Robert. 1978. "Les *Augustales.” ANRW II. 16: 1254-1309. Berlin.

Eriksen, Thomas H. 2010. Ethnicity and Nationalism: Anthropological Perspectives. 3rd. edn. New York. 
Fears, J. Rufus. 1975. “Cumae in the Roman Imperial Age.” Vergilius 21: 1-20.

Ferguson, John. 1987. A Prosopography to the Poems of Juvenal. Collection Latomus 200. Brussels.

Frank, Tenney. 1916. "Race Mixture in the Roman Empire." AHR 21: 689-708.

Fredericks, S. C. 1972. "Daedalus in Juvenal's Third Satire.” CB 49: 11-13.

—. 1973. "The Function of the Prologue (1-20) in the Organization of Juvenal's Third Satire." Phoenix 27: 62-7.

Frederiksen, Martin. 1984. Campania. London.

Freudenburg, Kirk. 2001. Satires of Rome: Threatening Poses from Lucilius to Juvenal. Cambridge.

Freulund Jensen, B. 1986. "Martyred and Beleaguered Virtue: Juvenal's Portrait of Umbricius." C\&M 37: 185-97.

Galinsky, Karl. 1992. Classical and Modern Interactions: Postmodern Architecture, Multiculturalism, Decline, and Other Issues. Austin, TX.

Garnsey, Peter. 1975. "Descendants of Freedmen in Local Politics: Some Criteria." In The Ancient Historian and his Materials: Essays in honour of C. E. Stevens on his seventieth birthday, edited by B. Levick, pp. 167-80. Farnborough.

Glazer, Nathan and Moynihan, Daniel P. 1963. Beyond the Melting Pot. Cambridge, MA. Goodman, Martin. 1989. "Nerva, the Fiscus Judaicus and Jewish Identity." JRS 79: 40-4. Gordon, Mary L. 1924. "The Nationality of Slaves under the Early Roman Empire.” JRS 14: 93111.

Gowers, Emily. 1993. The Loaded Table: Representations of Food in Roman Literature. Oxford. Griffith, John G. 1951. "Varia Iuvenaliana.” $C R$ 1: 138-42. 
Gruen, Erich S. 1992. Culture and National Identity in Republican Rome. Ithaca, NY.

Gumperz, John J. 1982. Discourse Strategies. Cambridge.

Hall, Jonathan M. 2002. Hellenicity: Between Ethnicity and Culture. Chicago, IL.

Hardie, Alex. 1998. "Juvenal, the Phaedrus, and the Truth about Rome." CQ 48: 234-51.

Harris, William V. 1979. War and Imperialism in Republican Rome 327-70 B.C. Oxford.

—. 1980. "Towards a Study of the Roman Slave Trade." In The Seaborne Commerce of

Ancient Rome: Studies in Archaeology and History, edited by J. H. D'Arms and E. C. Kopff.

MAAR 36, pp. 117-40. Rome.

Henderson, John. 1999. Writing down Rome: Satire, Comedy, and other Offences in Latin

Poetry. Cambridge.

Highet, Gilbert. 1951. “Juvenal's Bookcase.” AJP 72: 369-94.

—. 1954. Juvenal the Satirist: A Handbook. Oxford.

—. 1974. "Masks and Faces in Satire." Hermes 102: 321-37.

Hooley, Daniel M. 2007. Roman Satire. Malden, MA.

Housman, A. E. 1921. "The application of thought to textual criticism." PCA 18: 67-84 (= The

Classical Papers of A. E. Housman III, 1058-69).

—_. [1905] 1931. D. Iunii Iuvenalis Saturae. Editorum in Usum Edidit. 2nd edn. Cambridge.

Iddeng, Jon W. 2000. "Juvenal, Satire and the Persona Theory: Some Critical Remarks." SO 75: $107-29$.

Isaac, Benjamin. 2004. The Invention of Racism in Classical Antiquity. Princeton, NJ.

—. 2011. "Attitudes toward Provincial Intellectuals in the Roman Empire." In Cultural Identity in the Ancient Mediterranean, edited by E. Gruen, pp. 491-518. Los Angeles. 
Jackson, Kenneth T. 1985. Crabgrass Frontier: The Suburbanization of the United States. Oxford.

Jahn, Otto. 1851. D. Iunii Iuvenalis Saturarum Libri V cum Scholiis Veteribus. Berlin.

Jenkyns, Richard. 2013. God, Space, \& City in the Roman Imagination. Oxford.

Jones, Frederick. 2007. Juvenal and the Satiric Genre. London.

Kaimio, Jorma. 1979. The Romans and the Greek Language. Helsinki.

Kaster, Robert A. 2005. Emotion, Restraint and Community in Ancient Rome. Oxford.

Keane, Catherine C. 2006. Figuring Genre in Roman Satire. Oxford.

Kernan, Alvin. 1959. The Cankered Muse. Satire of the English Renaissance. New Haven, CT.

Knoche, Ulrich. 1940. Handschriftliche Grundlagen des Juvenaltextes. Phil. Suppl. 33. Leipzig.

—. 1950. D. Iunius Juvenalis Saturae mit kritishem Apparat. Munich.

Konstan, David. 2001. "To Hellēnikon ethnos: Ethnicity and the Construction of Ancient Greek Identity." In Ancient Perceptions of Greek Ethnicity, edited by I. Malkin, pp. 29-50. Cambridge, MA.

LaFleur, Richard A. 1975. “Amicus and Amicitia in Juvenal.” CB 51: 54-6.

—. 1976. "Umbricius and Juvenal Three." ZA 26: 383-431.

Larmour, David H. J. 2007. "Holes in the body: sites of abjection in Juvenal's Rome.” In The

Sites of Rome: Time, Space, Memory, edited by D. Larmour and D. Spencer, pp. 168-210. Oxford.

Laurence, Ray. 1997. "Writing the Roman Metropolis.” In Roman Urbanism: Beyond the Consumer City, edited by H. Parkins, pp. 1-20. London.

Lear, Norman. 1971. “As I Read How Laura Saw Archie...” New York Times, October 10, 1971. Leo, Frederich. 1910. A. Persii Flacci, D. Iunii Iuvenalis, Sulpiciae Saturae. Berlin. 
Maas, Paul. 1958. Textual Criticism, trans. Barbara Flower. Oxford.

Martyn, John R. C. 1987. D. Iuni Iuvenalis Saturae. Amsterdam.

Mayor, John E. B. 1872. Thirteen Satires of Juvenal with a Commentary. London.

McCabe, Kevin. 1986. "Was Juvenal a Structuralist? A Look at Anachronisms in Literary Criticism." G\&R 33: 78-84.

Miller, Paul Allen. 2005. Latin Verse Satire: An Anthology and Critical Reader. New York.

Moerman, Michael. 1965. "Ethnic Identification in a Complex Civilization: Who Are the Lue?" American Anthropologist 67: 1215-30.

Moodie, Erin K. 2012. “The Bully as Satirist in Juvenal's Third Satire.” AJP 133: 93-115.

Motto, Anna Lydia and Clark, John R. 1965. "Per iter tenebricosum: The Mythos of Juvenal 3." TAPA 96: 267-76.

Mouritsen, Henrik. 2011. The Freedman in the Roman World. Cambridge.

Nisbet, Robin G. M. 1989. “On Housman’s Juvenal.” ICS 14: 285-302.

O’Sullivan, J. N. 1978. "Parody and Sense in Juvenal 3.198-202.” AJP 99: 456-8.

Park, Robert Ezra. [1939] 1950. “The Nature of Race Relations.” In Race and Culture, pp. 81116. Glencoe, IL.

Peel, John D. Y. 1989. “The Cultural Work of Yoruba Ethnogenesis.” In History and Ethnicity, edited by E. Tonkin, M. McDonald and M. Chapman, pp. 198-215. London.

Plaza, Maria. 2006. The Function of Humour in Roman Verse Satire: Laughing and Lying. Oxford.

Pöschl, Viktor. 1962. The Art of Vergil: Image and Symbol in the Aeneid, trans. G. Seligson. Ann Arbor, MI.

Putnam, Michael C. J. 1998. Virgil's Epic Designs: Ekphrasis in the Aeneid. New Haven, CT. 
Rimell, Victoria. 2005. “The Poor Man's Feast: Juvenal.” In The Cambridge Companion to Roman Satire, edited by K. Freudenburg, pp. 81-94. Cambridge.

Romeo, I. 2002. “The Panhellenion and Ethnic Identity in Hadrianic Greece.” CP 97: 21-40.

Rosen, Ralph M. 2007. Making Mockery. The Poetics of Ancient Satire. Oxford.

—. 2012. "Efficacy and Meaning in Ancient and Modern Political Satire: Aristophanes, Lenny Bruce, and Jon Stewart.” Social Research 79: 1-32.

Rudd, Niall. 1986. Themes in Roman Satire. Norman, OK.

Ruperti, George A. 1801. D. Junii Juvenalis Aquinatis Satirae XVI. Leipzig.

Sarkissian, John. 1991. “Appreciating Umbricius: The Prologue (1-20) of Juvenal's Third Satire." $C \& M$ 42: 247-58.

Scheidel, Walter. 2005. "Human Mobility in Roman Italy, II: The Slave Population." JRS 95: 64-79.

—. 2011. "The Roman Slave Supply." In The Cambridge World History of Slavery. Volume I: The Ancient Mediterranean World, edited by K. Bradley and P. Cartledge, pp. 287-310. Cambridge.

Scotton, Carol M. 1988. "Code switching as indexical of social negotiations." In Codeswitching: Anthropological and Sociolinguistic Perspectives, edited by M. Heller, pp. 151-86. Berlin.

Sedley, David. 1999. "Lucretius' Use and Avoidance of Greek." In Aspects of the Language of Latin Poetry, edited by J. N. Adams and R. G. Mayer. Proceedings of the British Academy 93, pp. 227-46. Oxford.

Serafini, Augusto. 1957. Studio sulla Satira di Giovenale. Florence.

Sherwin-White, A. N. 1967. Racial Prejudice in Imperial Rome. Cambridge.

—. 1973. The Roman Citizenship. 2nd edn. [orig. 1939]. Oxford. 
Smith, Warren S. 1997. "Juvenal and the Sophist Isaeus." CW 91: 39-45.

Solin, Heikki. 1971. Beiträge zur Kenntnis der griechischen Personennamen in Rom. Helsinki.

Staley, Gregory A. 2000. “Juvenal's Third Satire: Umbricius' Rome, Vergil's Troy.” MAAR 45: $85-98$.

Sugrue, Thomas J. 1996. The Origins of the Urban Crisis: Race and Inequality in Postwar Detroit. Princeton, NJ.

Swain, Simon. 1996. Hellenism and Empire: Language, Classicism, and Power in the Greek World AD 50-250. Oxford.

—. 2002. "Bilingualism in Cicero? The Evidence of Code-Switching." In Bilingualism in Ancient Society: Language Contact and Written Text, edited by J. N. Adams, M. Janse and S. Swain, pp. 128-67. Oxford.

Syme, Ronald. 1960. "The Greeks under Roman Rule.” Proceedings of the Massachusetts Historical Society 72: 3-20 (= Roman Papers II, 566-81).

Teuffel, Wilhelm. 1865. "Zu Juvenal." RhM 20: 473-9.

Thiel, Augustus. 1901. Iuvenalis Graecissans, sive de Vocibus Graecis apud Iuvenalem. Dreslau. Thompson, Dorothy J. 2001. "Hellenistic Hellenes: The Case of Ptolemaic Egypt.” In Ancient Perceptions of Greek Ethnicity, edited by Irad Malkin, pp. 301-22. Cambridge, MA.

Vidmar, Neil and Rokeach, Milton, 1974. “Archie Bunker’s Bigotry: A Study in Selective Perception and Exposure." Journal of Communication 24: 36-47.

Wallace-Hadrill, Andrew. 1998. “To Be Roman, Go Greek: Thoughts on Hellenization at Rome." In Modus Operandi: Essays in Honour of Geoffrey Rickman, edited by M. Austin, J. Harries and C. Smith, pp. 79-91. London. 
Wallerstein, Immanuel. 1960. "Ethnicity and National Integration in West Africa.” Cahiers d'études africaines 1: 129-39.

Wardman, Alan. 1976. Rome's Debt to Greece. London.

Watts, W. J. 1976. "Race Prejudice in the Satires of Juvenal.” AClass 19: 83-104.

Webster, Jane. 2010 "Routes to slavery in the Roman world: a comparative perspective on the archaeology of forced migration." In Roman Diasporas: Archaeological Approaches to Mobility and Diversity in the Roman Empire, edited by H. Eckardt. JRA Suppl. 78, pp. 45-65. Portsmouth, RI.

Wehrle, William T. 1992. The Satiric Voice: Program, Form and Meaning in Persius and Juvenal. Hildesheim.

Weise, Oscar. [1882] 1964. Die Griechischen Wörter im Latein. Leipzig.

Wessner, Paul. [1931] 1977. Scholia in Iuvenalem Vetustiora. Stuttgart.

Wiesen, David. 1963. “Juvenal's Moral Character, an Introduction.” Latomus 22: 440-71.

Willis, James. 1997. D. Iunii Iuvenalis Saturae Sedecim. Stuttgart.

Winkler, Martin M. 1983. The Persona in Three Satires of Juvenal. Hildesheim.

Witke, E. C. 1962. “Juvenal III: Eclogue for the Urban Poor.” Hermes 90: 244-8. 